\title{
KONTRIBUSI ANTARA KOORDINASI MATA TANGAN DAN KECEPATAN REAKSI TANGAN TERHADAP PUKULAN FOREHAND DALAM PERMAINAN TENISMEJA PADA SISWA SMA NEGERI 1 MARIORIAWA KABUPATEN SOPPENG
}

\author{
Nurliati Syamsuddin ${ }^{1}$, Hamdiana $^{2}$, Ulfa $^{3}$
}

\section{Keywords :}

Koordinasi Mata Tangan;

Kecepatan Reaksi Tangan;

Pukulan Forehand

Tenismeja

\section{Corespondensi Author \\ ${ }^{1}$ Universitas Negeri Makassar, nurliati.syamsuddin@unm.ac.id \\ ${ }^{2}$ Universitas Mulawarman, hamdianapjkr11@gmail.com \\ ${ }^{3}$ Dinas Pendidikan Provinsi Sulawesi Selatan, ulfakhalfani@gmail.com}

\author{
Article History \\ Received: Agustus; \\ Reviewed: September; \\ Accepted: September; \\ Published: Oktober
}

\begin{abstract}
ABSTRAK
Penelitian ini bertujuan untuk mengetahui kontribusi koordinasi mata tangan dan kecepatan reaksi tangan terhadap pukulan forehand dalam permainan tenismeja. Penelitian ini termasuk jenis penelitian deskriptif berkorelasional. Populasi penelitian ini adalah seluruh siswa laki-laki SMA Negeri 1 Marioriawa Kabupaten Soppeng dengan jumlah sampel penelitian 40 orang yang dipilih secara random sampling. Teknik analisis data yang digunakan adalah teknik analisis korelasi dan regresi dengan menggunakan program SPSS Versi 21.00 pada taraf signifikan 95\% atau $\alpha_{0,05}$. Bertolak dari hasil analisis data, maka penelitian ini menyimpulkan bahwa: (1) Koordinasi mata tangan berkontribusi secara signifikan terhadap pukulan forehand dalam permainan tenismeja sebesar 69,1\%; (2) Kecepatan reaksi tangan berkontribusi secara signifikan terhadap pukulan forehand dalam permainan tenismeja sebesar 52,8\%; dan (3) Koordinasi mata tangan dan kecepatan reaksi tangan berkontribusi secara signifikan terhadap pukulan forehand dalam permainan tenismeja sebesar 69,5\%
\end{abstract}

\section{PENDAHULUAN}

Salah satu cabang olahraga yang banyak digemari, mulai dari anak-anak sampai orang dewasa baik laki-laki maupun perempuan. Kenyataan ini disebabkan karena cukup dengan sebuah meja yang tidak membutuhkan tempat yang luas serta alat pemukul dan bola serta net sudah dapat bermain tenismeja. Oleh sebab itu tidak mengherankan kalau permainan tenismeja ini dikenal mulai dari kota-kota besar sampai di daerah pedesaan. Dengan demikian tentu digemari oleh banyak orang sehingga kemungkinan peluang untuk berprestasi cukup besar. Akan tetapu apa yang diharapkan belum terwujud, sehingga diperlukan berbagai usaha dalam mengidentifikasikan berbagai hal yang perlu diperhatikan dalam pelaksanaan pembinaan tenismeja. Cabang olahraga permainan tenismeja adalah Untuk dapat berprestasi dalam suatu cabang olahraga termasuk cabang olahraga permainan tenismeja yaitu memiliki keterampilan cabang olahraga tersebut, serta ditunjang oleh unsur fisik. Salah satu metode yang terbaik untuk meningkatkan keterampilan yaitu secara langsung mempelajari kegiatan yang dimaksud melalui kegiatan praktek secara langsung dan 


\section{e-ISSN: 2657-0703 dan p-ISSN: 2085-5389}

berulang-ulang tekanannya pada pembiasaan fisik. Berdasarkan hasil observasi yang peneliti lakukan di SMA Negeri 1 Marioriawa Kabupaten Soppeng bahwa kemampuan pukulan forehand dalam permainan tenismejasiswa belum dapat dilakukan optimal. Hal ini dapat disebabkan oleh kedua kondisi fisik yaitu koordinasi mata tangan dan kecepatan reaksi tangan sebagai faktor pendukung melakukan forehand yang belum maksimal. Berbagai cara latihan serta bentukbentuk latihan fisik yang dipergunakan pelatih dan pembina olahraga tenismeja, dapat menimbulkan keraguan untuk memilih metode dan bentuk latihan fisik yang dipergunakan oleh para pelatih dan pembinan olahraga tenismeja dapat saja menimbulkan kemajuan untuk memilih metode dan bentuk latihan fisik yang tepat pada suatu tingkat dan pembinaan tertentu. Bentuk-bentuk latihan fisik cukup banyak dan bervariasi. Latihanlatihan fisik yang menunjang peningkatan kemampuan pukulan forehand pada permainan tenismeja adalah koordinasi mata tangan dan kecepatan reaksi tangan. Koordinasi mata tangan dalam permainan tenismeja sangat dibutuhkan dalam hal mengantisipasi bola-bola yang datang ke berbagai arah. Dalam permainan tenismeja laju bola yang datang sangat cepat dan tidak dapat diduga kemana arah bola tersebut. Dengan memiliki koordinasi gerak yang baik terutama koordinasi gerak antara mata tangan dan tangan, akan membantu mempersiapkan jawaban yang harus dilakukan terhadap rangsangan yang datang. Kecepatan reaksi tangan dalam permainan tenismeja terutama untuk melakukan pukulan forehand sangat berperan. Dengan memiliki pergerakan tangan yang cepat akan memudahkan dalam melakukan pukulan dengan cepat menjangkau bola-bola sulit yang ditempatkan oleh pihak lawan. Kondisi fisik merupakan faktor yang paling utama dalam peningkatan prestasi bagi seorang atlet. Kondisi fisik adalah satu kesatuan dari komponen-komponen yang tidak dapat dipisahkan, baik peningkatannya maupun pemeliharaannya. Waharsono dan Sajoto (2007:129) bahwa: "Kondisi fisik adalah suatu kesatuan utuh dari komponenkomponen yang tidak dapat dipisahkan, baik peningkatannya maupun pemeliharaannya". Selanjutnya diungkapkan bahwa: "diperlukan berbagai persiapan dengan prioritas urutan adalah persiapan fisik, persiapan teknik, persiapan taktik, dan persiapan mental". Artinya bahwa di dalam usaha peningkatan kondisi fisik, maka seluruh komponen tersebut harus di kembangkan. Walaupun disana-sini dilakukan dengan sistem prioritas sesuai keadaan atau status yang dibutuhkan tersebut, maka perlu diketahui selanjutnya adalah bagaimana seorang atlet dapat diketahui status dan keadaan kondisi fisiknya pada suatu saat. Sedangkan setiap usaha peningkatan latihan kondisi fisik, maka harus mengembangkan semua komponen tersebut. Walaupun perlu dilakukan dengan sistem prioritas. Pengembangan fungsional dan sistem tubuh yang baik, dapat menunjang pelaksanaan teknik gerakan secara optimal. Harsono (dalam Tangkudung, 2006:62) bahwa kondisi fisik yang baik akan berpengaruh terhadap fungsi dan sistem organisme tubuh, antara lain berupa: (1) Akan ada peningkatan dalam kemampuan sistem sirkulasi dan kerja jantung, (2) Akan ada peningkatan dalam kekuatan, kelentukan, stamina, dan komponen kondisi fisik lainnya, (3) Akan ada ekonomi gerak yang lebih baik waktu latihan, (4) Akan ada pemulihan yang lebih cepat dalam organ-organ tubuh setelah latihan, dan (5) Akan ada respon yang cepat dari organisme tubuh kita apabila sewaktu-waktu respon demikian diperlukan. Dengan latihan kondisi fisik, teknik, mental dan sebagainya dapat diketahui peningkatannya karena untuk meningkatkan fisik tidak dapat dilakukan dengan permainan itu sendiri. Mengapa faktor fisik? Karena faktor kondisi fisik memegang peranan penting dan merupakan komponen dasar untuk menuju latihan-latihan berikutnya, kalau tidak di dukung dengan kondisi fisik yang prima seorang atlet tidak akan mampu melakukan latihan sesuai dengan porsinya, nilai fisik antara lain kualitas otot berdasarkan kinerja faal dan mekanisme otot yang sedang bekerja yang dipertimbangkan pada kekuatan otot, kapasitas anaerobik, kapasitas aerobikpower, fleksibilitas. Yudiana, Subardjah dan Juliantine (2013:1) mengatakan bahwa: Latihan kondisi fisik adalah proses memperkembangkan kemampuan aktivitas gerak jasmani yang dilakukan secara sistematik dan ditingkatkan secara progresif untuk mempertahankan atau meningkatkan derajat kebugaran jasmani agar tercapai kemampuan kerja fisik yang optimal.

Koordinasi merupakan salah satu elemen kondisi fisik yang relatif sulit didefenisikan 


\section{Volume 10 Nomor 3, Oktoberi 2018}

secara tepat karena fungsinya sangat terkait dengan elemen-elemen kondisi fisik yang lain dan sangat ditentukan oleh kemampuan siswa. Koordinasi adalah kemampuan untuk berulang kali mengeksekusi urutan gerakan lancar dan akurat. Ini mungkin melibatkan indra, kontraksi otot dan gerakan sendi. Koordinasi adalah kemampuan untuk melakukan gerakan atau kerja dengan tepat dan efisien. Tangkudung dan Puspitorini (2012:72) bahwa: "Koordinasi adalah kemampuan untuk melakukan gerakan dengan berbagai tingkat kesukaran dengan cepat dan efesien dan penuh ketepatan". Koordinasi ini menyatakan hubungan harmonis berbagai factor yang terjadi pada suatu gerakan. Koordinasi adalah yang berhubungan dengan kemampuan untuk menggunakan panca indera seperti penglihatan dan pendengaran, bersama-sama dengan tubuh tertentu di dalam melakukan kegiatan motorik dan harmonis dan ketepatan tinggi. Menurut Bompa (1983) (dalam Harsono, 1988:219) bahwa: "Koordinasi adalah suatu kemampuan biomotorik yang sangat kompleks. Koordinasi erat hubungannya dengan kecepatan, kekuatan, daya tahan, dan fleksibilitas". Oleh karena itu, bentuk latihan koordinasi harus dirancang dan disesuaikan dengan unsur-unsur kecepatan, kekuatan, daya tahan, dan kelentukan. Koordinasi adalah kemampuan seseorang mengintegrasikan bermacam-macam gerakan yang berbeda kedalam pola gerakan tunggal secara efektif. Jadi koordinasi merupakan suatu aktivitas beberapa sistem tubuh dan pola pergerakan untuk membentuk gerakan individu dan keterampilan yang diperlukan untuk tujuan tertentu. Koordinasi mata-tangan sangat penting baik di lapangan maupun di luar lapangan, terutama permainan seperti tenismeja yang membutuhkan berbagai macam gerakan-gerakan kompleks. Koordinasi mata-tangan adalah suatu kemampuan biometric yang kompleks yang mempunyai kontribusi erat dengan kecepatan, kekuatan, daya tahan dan kelentukan. Dalam permainan tenismeja khususnya teknik dasar pukulan forehand membutuhkan gerakan yang kompleks, yang merupakan syarat utama dalam teknik tersebut. Koordinasi mata dan tangan adalah gerak yang terjadi dari informasi yang diintegrasikan ke dalam gerak anggota badan. Semua gerakan tangan harus dapat dikontrol dengan penglihatan dan harus tepat, sesuai dengan urutan yang direncanakan untuk melakukan gerakan pukulan forehand. Melakukan pukulan forehand, semua memerlukan sejumlah input yang dapat dilihat, kemudian input tadi diintegrasikan ke dalam gerak motorik sebagai output, agar hasilnya merupakan gerakan yang tekoordinasi secara luwes. Seorang pemain tenismeja yang memiliki koordinasi matatangan yang baik, maka mampu mengkoordinasikan komponen-komponen penggerakan tubuh, otot-otot, tendo dan persendian sebagai komponen utama dalam permainan tenismeja khususnya dalam melakukan teknik pukulan forehand.

Kecepatan reaksi dalam istilah sebenarnya adalah waktu reaksi (reaction time) adalah gerak pertama yang dilakukan setelah menerima rangsangan (stimulus). Waktu reaksi sangat dibutuhkan pada pemain tenismeja. Cabang olahraga ini memerlukan kecepatan gerak yakni kemampuan melakukan gerakan awal setelah stimulus diterima. Kemampuan bereaksi akan menentukan proses gerakan selanjutnya termasuk pukulan-pukulan yang baik. Pemain tenismeja yang mempunyai kecepatan reaksi lebih baik akan mampu melakukan gerakan pukulan lebih efektif sehingga pukulan yang dilakukan lebih cepat dan terarah. Dalam permainan tenismeja, gerakan-gerakan yang dilakukan untuk memukul bola secara cepat dan tepat memerlukan kecepatan reaksi lengan untuk mengantisipasi bola. Bola yang dipukul oleh lawan merupakan stimulus yang datang dan memerlukan kemampuan untuk melakukan reaksi terhadap stimulus tersebut dengan cara memukul bola sehingga dapat dikembalikan ke lapangan lawan pada sasaran yang tepat. Keterlambatan melakukan reaksi terhadap bola yang datang dapat menyebabkan antisipasi kurang akurat sehingga pukulan yang dilakukan tidak sempurna atau tidak terarah, tersangkut di net, dan keluar lapangan permainan. Waktu reaksi seringkali dirancukan dengan istilah lain seperti refleks dan kecepatan gerak (movement speed). Menurut Harsono (1988:217) bahwa "waktu reaksi adalah waktu antara pemberian rangsangan (stimulus) dengan gerakan pertama". Ketika seseorang bermain tenismeja, gerakan-gerakan yang dilakukan untuk memukul bola atau bergerak ke arah bola untuk mengantisipasi pukulan lawan merupakan respon terhadap stimulus yang 


\section{e-ISSN: 2657-0703 dan p-ISSN: 2085-5389}

datang. Respon tersebut berupa kecepatan reaksi lengan untuk memukul bola yang relatif cepat. Pemain tenismeja yang mempunyai reaksi lambat, tentu akan menemui kesulitan untuk mengembangkan permainannya, oleh karena bola yang dimainkan relatif kecil dan bergerak lebih cepat di atas meja sehingga menuntut ketelitian tentang arah reaksi yang dilakukan (daya antisipasi secara tepat). Banyak pemain tenismeja yang tidak mampu mengatasi permainan lawan atau sulit mengembangkan tipe permainannya karena reaksinya lebih lambat daripada lawannya, sehingga pukulan-pukulan pengembalian bola yang dilakukan memudahkan lawan untuk menyerang. Kecepatan reaksi tidak berarti kemampuan melakukan gerakan secepat mungkin secara berulang-ulang dalam waktu yang terbatas. Akan tetapi kecepatan reaksi ditentukan oleh kemampuan bergerak dengan cepat setelah adanya stimulus yang dapat berupa pendengaran, penglihatan, dan sebagainya.Untuk mencapai tingkat kecepatan maksimal, kecepatan reaksi sangat menunjang sebagai penentu gerakan selanjutnya. Menurut Wilmore (1977) yang dikutip oleh Harsono (1988:216) bahwa "kecepatan tergantung dari beberapa faktor yang mempengaruhi, yaitu strength, waktu reaksi (reaction time), dan flexibility". Sehingga dianjurkan agar dalam berlatih untuk memperkembangkan kecepatan gerak dalambermain tenismeja, harus pula dilatih kekuatan, kecepatan reaksi, kelentukan, dan tidak hanya semata-mata berlatih kecepatan saja. Kecepatan reaksi merupakan koordinasi kerja otot dan syaraf yang menentukan gerakan-gerakan secara terampil dalam bermain tenismeja. Dalam bermain tenismeja, gerakan-gerakan yang dilakukan untuk memukul bola atau untuk mengantisipasi pukulan lawan menuntut kecepatan reaksi tangan melalui pendengaran dan penglihatan. Kecepatan reaksi motorik ditentukan oleh kemampuan bergerak ke arah bola sambil memukul bola setelah bola tersebut datang dari pihak lawan. Kecepatan reaksi untuk memukul bola setelah bola tersebut datang dari pihak lawan. Kecepatan reaksi untuk memukul bola pada permainan tenismeja memerlukan koordinasi dan ketepatan gerakan. Pendengaran dan penglihatan sangat menunjang kecepatan reaksi dalam bermain tenismeja. Kecepatan reaksi tergantung pada proses rangsangan syaraf pendengaran dan syaraf perintah atau penglihatan. Rangsangan pendengaran misalnya pada bunyi bola yang dipukul oleh lawan atau bola yang terpantul pada meja menyebabkan pemain melakukan reaksi dengan cepat untuk memukul bola, sekaligus merupakan usaha untuk mengembalikan bola ke lapangan lawan. Rangsangan syaraf perintah yaitu setelah bola yang dipukul oleh lawan ke lapangan kita, menyebabkan syarafsyaraf spinal memberi perintah kepada lengan atau tangan untuk memukul bola yang datang sehingga bola dapat dikembalikan. Sedangkan rangsangan syaraf penglihatan yang menentukan kecepatan reaksi tangan, misalnya bola yang datang dari hasil pukulan lawan, melalui penglihatan kita sehingga menimbulkan rangsangan memukul bola yang datang ke lapangan permainan kita. Dengan demikian, untuk mempertahankan kecepatan reaksi tangan dalam bermain tenismeja, diperlukan kemampuan untuk berkonsentrasi sepanjang permainan. Konsentrasi untuk melakukan gerakan memukul bola pada permainan tenismeja, akan lebih baik daripada konsentrasi ditujukan pada bola yang datang, meskipun semuanya penting dan memerlukan konsentrasi. Meskipun tanpa konsentrasi terhadap bola, bola tersebut akan kelihatan juga. Untuk itu konsentrasi yang lebih penting dalam bermain tenismeja adalah terhadap jenis gerakan atau pukulan yang akan dilakukan pada bola yang datang sehingga proses gerakan memukul bola dapat dilakukan dengan tepat, tanpa gerakan ragu-ragu atau kaku. Harsono (1988:218) mencontohkan bahwa "... para pelari sprint dianjurkan agar pada waktu berada dalam sikap "siap", konsentrasi pada start yang baik, dan bukan pada bunyi pistol". Tanpa berkonsentrasi pada bunyi pistol, bunyinya akan tetap terdenagar juga. Cabang olahraga yang banyak memerlukan kecepatan reaksi tangan, seperti tenismeja sangat penting melatih konsentrasi agar dapat dimanfaatkan dalam permainan dan mampu mempertahankan konsentrasi tersebut meskipun permainan berlangsung lama.

Keterampilan diartikan sebagai suatu kesanggupan menggunakan pengetahuan seseorang secara efektif dan siap dalam pelaksnaaan penampilan (performance), serta mencapai kemantapan dari suatu keberhasilan dalam mencapai tujuan. Keterampilan yang dimaksud disini adalah keterampilan gerak (motor skill). Menurut Clarke (1979:8) bahwa : 


\section{Volume 10 Nomor 3, Oktoberi 2018}

"Motor skill is a motor activity limited in extent involving and single movement or a limites group of movement are performed with high degree of percission and accuracy. Pengertian bebas dari batasan di atas adalah bahwa keterampilan gerak yaitu gerakan yang dibatasi dalam ruang serta pengaruh gerakan tunggal atau gerakan berangkai yang dalam penampilannya disertai dengan derajat kecermatan dan keterampilan yang tinggi. Berdasarkan pendapat di atas maka suatu gerakan dikategorikan sebagai gerakan terampil apabila dilakukan dengan teliti dan tepat dalam kondisi gerakan dengan faktor kesulitan yang tinggi. Tinggi rendahnya faktor kesulitan suatu gerakan ditentukan oleh tingkat keterampilan dari orang yang melakukan. Keterampilan yang dimaksudkan di sini adalah keterampilan pukulan forehand dan backhand dalam permainan tenismeja. Permainan tenismeja termasuk salah satu cabang olahraga yang dipertandingkan dalam berbagai pesta olahraga. Sehingga cabang olahraga ini cukup dikenal. Pelaksanaannya ditandai dengan memukul bola secara berganti-ganti (bolak-balik) terpantul pada meja dan melewati atas net. Soetomo (1981:541) mengemukakan: "Permainan tenismeja adalah suatu jenis permainan yang menggunakan meja tempat untuk memantulkan bola yang dipukul oleh seorang pemain dan bola tersebut harus melewati net atau jaring yang dipasang pada tengah lapangan. Oleh karena permainan tenismeja sebagai suatu cabang olahraga tentunya terdiri dari serangkaian teknik pelaksanaan yang harus dilakukan sesuai dengan ketentuan peraturan cabang olahraga tersebut. Dari berbagai teknik dasar pada umumnya teknik dasar stroke atau pukulan yang lebih banyak menjadi perhatian dalam pembinaan cabang olahraga permainan tenismeja. Hal ini disebabkan karena permainan tenismeja lebih banyak memanfaatkan pukulan dalam permainan. Teknik dasar pukulan pokok yaitu pukulan forehand dan pukulan backhand. Pengertian dari pukulan forehand dan pukulan backhand diartikan sebagai berikut: Yang dimaksud dengan forehand drive yaitu memukul bola dengan bagian depan alat pemukul yang pada dasarnya adalah pengayunan tangan yang memegang alat pemukul dari luar atau dari samping ke dalam. Sedangkan yang dimaksud dengan backhand drive yaitu memukul bola dengan bagian belakang atau bagian depan alat pemukul yang pada dasarnya lengan diayunkan dari dalam keluar. (Abd. Hamid Tjato, 1980: 30). Pemain tenismeja tidak boleh hanya melatih satu pukulan saja. Pemain harus menguasai berbagai macam pukulan, karena masingmasing pukulan mempunyai sifat yang berlainan seperti power (kekuatan pukulan), length (panjang pukulan), dan touch (sentuhan pukulan, sentuhan bat dengan bola). Ketiga aspek tersebut berbeda-beda bagi setiap macam pukulan, dengan kombinasi-kombinasi beraneka ragam. Setiap pukulan terdiri dari bermacam-macam gerakan yang terpadu menjadi satu yang dibagi atas tipe menurut Peter Simpson (1986:64) yaitu; short (pendek), medium (sedang), dan long (panjang)". Panjang pendeknya pukulan tergantung dari jenis pukulan itu sendiri, tujuan yang ingin dicapai dn zone tepat kita bermain.

\section{METODE PENELITIAN}

Metode yang di pergunakan dalam penelitian ini adalah metode deskriptif. Dalam pelaksanaan penelitian terdapat dua variabel yang menjadi fokus, sebagai berikut: (1) Variabel bebas yaitu koordinasi mata tangan dan kecepatan reaksi tangan, dan (2) variabel terikat yaitu pukulan forehand permainan tenismeja. Desain penelitian yang digunakan dalam penelitian adalah korelasional. Populasi dalam penelitian ini adalah seluruh siswa SMA Negeri 1 Marioriawa dengan jenis kelamin laki-laki sebanyak 120 orang, maka sampel yang diambil atau digunakan dalam penelitian ini berjumlah 40 orang yang diambil $30 \%$ dari 120 orang siswa laki-laki SMA Negeri 1 Marioriawa dengan menggunakan teknik random sampling. Data yang terkumpul tersebut perlu dianalisis secara statistik deskriptif, maupun infrensial untuk keperluan pengujian hipotesis penelitian. Keseluruhan analisis data statistik diolah dengan menggunakan analisis program SPSS versi 21.00 dengan taraf signifikan $95 \%$ atau $\alpha_{0,05}$.

\section{HASIL DAN PEMBAHASAN Hasil Penelitian}

Analisis deskriptif dilakukan terhadap data koordinasi mata tangan, kecepatan reaksi tangan, dan pukulan forehand dalam permainan tenismeja pada siswa SMA Negeri 1 Marioriawa Kabupaten Soppeng. Analisis deskrtiptif meliputi; total nilai, rata-rata, 


\section{e-ISSN: 2657-0703 dan p-ISSN: 2085-5389}

range, maksimal dan minimum. Dari nilainilai statistik ini diharapkan dapat memberi gambaran umum tentang keadaan data koordinasi mata tangan, kecepatan reaksi tangan, dan pukulan forehand dalam permainan tenismeja. Hasil analisis deskriptif setiap variabel penelitian dapat dilihat dalam tabel 1.

Tabel 1.

Hasil analisis deskriptif tiap variabel.

\begin{tabular}{|l|c|r|c|c|c|c|c|}
\hline \multicolumn{1}{|c|}{$\begin{array}{c}\text { Variabel / } \\
\text { Statistik }\end{array}$} & $\mathrm{N}$ & Sum & Mean & Stdv & Range & Min. & Max. \\
\hline $\begin{array}{l}\text { Koordinasi mata } \\
\text { tangan }\end{array}$ & 40 & 527,00 & 13,1750 & 1,76704 & 6,00 & 10,00 & 16,00 \\
\hline $\begin{array}{l}\text { Kecepatan reaksi } \\
\text { tangan }\end{array}$ & 40 & 668,00 & 16,7000 & 2,76610 & 9,00 & 12,00 & 21,00 \\
\hline $\begin{array}{l}\text { Pukulan } \\
\text { forehand } \\
\text { tenismeja }\end{array}$ & 40 & 644,00 & 16,1000 & 2,20489 & 9,00 & 12,00 & 21,00 \\
\hline
\end{tabular}

Untuk pengujian hipotesis tersebut maka dilakukan uji korelasi dan regresi data koordinasi mata tangan, kecepatan reaksi tangan dan pukulan forehand dalam permainan tenismeja pada siswa SMA Negeri 1 Marioriawa Kabupaten Soppeng.

a. Ada kontribusi koordinasi mata tangan terhadap pukulan forehand dalam permainan tenismeja pada siswa SMA Negeri 1 Marioriawa Kabupaten Soppeng
Hasil data yang diperoleh dari penelitian bertujuan untuk mengetahui antara variable bebas dan variable terikat serta membuktikan hipotesis yang ada. Oleh karena itu hasil pengujian hipotesis berdasarkan pengolahan data melalui analisis korelasi dan regresi dari program SPSS tentang kontribusi koordinasi mata tangan terhadap pukulan forehand dalam permainan tenismeja pada siswa SMA Negeri 1 Marioriawa Kabupaten Soppeng diperoleh sesuai rangkuman tabel 3 berikut:

Tabel 2.

Hasil analisis korelasi dan regresi untuk hipotesis pertama

\begin{tabular}{|c|c|c|c|c|c|}
\hline VARIABEL & $\mathbf{r} / \mathbf{R}$ & Rs & $\mathbf{F}$ & $\mathbf{t}$ & Sig. \\
\hline $\begin{array}{l}\text { Koordinasi mata tangan } \\
\text { (X1) }\end{array}$ & \multirow{2}{*}{0,831} & \multirow{2}{*}{0,691} & \multirow{2}{*}{84,934} & \multirow{2}{*}{9,216} & \multirow{2}{*}{0,000} \\
\hline $\begin{array}{l}\text { Pukulan forehand dalam } \\
\text { permainan tenismeja (Y) }\end{array}$ & & & & & \\
\hline
\end{tabular}

Hipotesis statistik yang akan di uji:

$\mathrm{H}_{0}: \mathrm{Rx}_{1 . \mathrm{y}}=0$

$\mathrm{H}_{1}: \mathrm{Rx}_{1 . \mathrm{y}} \neq 0$

Hasil pengujian:

Berdasarkan hasil pengujian analisis data antara koordinasi mata tangan terhadap pukulan forehand dalam permainan tenismeja pada siswa SMA Negeri 1 Marioriawa Kabupaten Soppeng. Diperoleh nilai korelasi 0,831 dengan tingkat probabilitas $(0,000)<\alpha_{0,05}$, untuk nilai $\mathrm{R}$ Square (koefesien determinasi) 0,691 . Hal ini berarti $69,1 \%$ pukulan forehand dalam permainan tenismeja dijelaskan oleh koordinasi mata tangan. Dari uji Anova atau $F$ test, didapat $F$ hitung adalah 61,037 dengan tingkat signifikansi 0,000 . Oleh karena probabilitas $(0,000)$ jauh lebih kecil dari $\alpha_{0,05}$, maka model regresi dapat dipakai 


\section{Volume 10 Nomor 3, Oktoberi 2018}

untuk memprediksi pukulan forehand dalam permainan tenismeja (dapat diberlakukan untuk populasi dimana sampel diambil). Dari uji t diperoleh 9,216 dengan tingkat signifikansi 0,000 . Oleh karena probabilitas $(0,000)$ jauh lebih kecil dari $\alpha_{0,05}$. Maka Ho ditolak dan $\mathrm{H}_{1}$ diterima atau koefesien regresi signifikan, atau koordinasi mata tangan benar-benar berpengaruh secara signifikan terhadap pukulan forehand dalam permainan tenismeja.

Dengan demikian dapat disimpulkan bahwa kontribusi koordinasi mata tangan terhadap pukulan forehand dalam permainan tenismeja pada siswa SMA Negeri 1 Marioriawa Kabupaten Soppeng sebesar $69,1 \%$. b. Ada kontribusi kecepatan reaksi tangan terhadap pukulan forehand dalam permainan tenismeja pada siswa SMA Negeri 1 Marioriawa Kabupaten Soppeng

Hasil data yang diperoleh dari penelitian bertujuan untuk mengetahui antara variable bebas dan variable terikat serta membuktikan hipotesis yang ada. Oleh karena itu hasil pengujian hipotesis berdasarkan pengolahan data melalui analisis korelasi dan regresi dari program SPSS tentang kontribusi kecepatan reaksi tangan terhadap pukulan forehand dalam permainan tenismeja pada siswa SMA Negeri 1 Marioriawa Kabupaten Soppeng diperoleh sesuai dari rangkuman tabel 3 berikut:

Tabel 3.

Hasil analisis korelasi dan regresi untuk hipotesis kedua

\begin{tabular}{|c|c|c|c|c|c|}
\hline VARIABEL & $\mathbf{r} / \mathbf{R}$ & Rs & $\mathbf{F}$ & $\mathbf{t}$ & Sig. \\
\hline $\begin{array}{l}\text { Kecepatan reaksi tangan } \\
\text { (X3) }\end{array}$ & \multirow{2}{*}{$-0,726$} & \multirow{2}{*}{0,528} & \multirow{2}{*}{42,470} & \multirow{2}{*}{$-6,517$} & \multirow{2}{*}{0,000} \\
\hline $\begin{array}{l}\text { Pukulan forehand dalam } \\
\text { permainan tenismeja (Y) }\end{array}$ & & & & & \\
\hline
\end{tabular}




\section{e-ISSN: 2657-0703 dan p-ISSN: 2085-5389}

Hipotesis statistik yang akan di uji:

$\mathrm{H}_{0}: \mathrm{Rx}_{2 . \mathrm{y}} \quad=0$

$\mathrm{H}_{1}: \mathrm{Rx}_{2 . \mathrm{y}} \neq 0$

Hasil pengujian:

Berdasarkan hasil pengujian analisis data antara kecepatan reaksi tangan terhadap pukulan forehand dalam permainan tenismeja pada siswa SMA Negeri 1 Marioriawa Kabupaten Soppeng. Diperoleh nilai korelasi dan regresi $-0,726$ dengan tingkat probabilitas $(0,000)<\alpha$ 0,05 , untuk nilai $\mathrm{R}$ Square (koefesien determinasi) 0,528. Hal ini berarti 52,8\% pukulan forehand dalam permainan tenismeja dijelaskan oleh kecepatan reaksi tangan. Dari uji Anova atau F test, didapat $F$ hitung adalah 42,470 dengan tingkat signifikansi 0,000 . Oleh karena probabilitas $(0,000)$ jauh lebih kecil dari $\alpha_{0,05}$, maka model regresi dapat dipakai untuk memprediksi pukulan forehand dalam permainan tenismeja (dapat diberlakukan untuk populasi dimana sampel diambil). Dari uji t diperoleh -6,517 dengan tingkat signifikansi 0,000 . Oleh karena probabilitas $(0,000)$ jauh lebih kecil dari $\alpha_{0,05}$. Maka Ho ditolak dan $\mathrm{H}_{1}$ diterima atau koefesien regresi signifikan, atau kecepatan reaksi tangan benar-benar berpengaruh secara signifikan terhadap pukulan forehand dalam permainan tenismeja. Dengan demikian dapat disimpulkan bahwa kontribusi kecepatan reaksi tangan terhadap pukulan forehand dalam permainan tenismeja pada siswa SMA Negeri 1 Marioriawa Kabupaten Soppeng sebesar $52,8 \%$.

c. Ada kontribusi koordinasi mata tangan, dan kecepatan reaksi tangan terhadap pukulan forehand dalam permainan tenismeja pada siswa SMA Negeri 1 Marioriawa Kabupaten Soppeng

Hasil data yang diperoleh dari penelitian bertujuan untuk mengetahui antara variable bebas dan variable terikat serta membuktikan hipotesis yang ada. Oleh karena itu hasil pengujian hipotesis berdasarkan pengolahan data melalui analisis regresi dari program SPSS tentang kontribusi koordinasi mata tangan dan kecepatan reaksi tangan terhadap pukulan forehand dalam permainan tenismeja pada siswa SMA Negeri 1 Marioriawa Kabupaten Soppeng diperoleh sesuai dari rangkuman tabel 4 berikut:

Tabel 4.

Hasil analisis regresi untuk hipotesis ketiga

\begin{tabular}{|c|c|c|c|c|c|}
\hline VARIABEL & $\mathbf{r} / \mathbf{R}$ & Rs & $\mathbf{F}$ & $\mathbf{t}$ & Sig. \\
\hline $\begin{array}{l}\text { Koordinasi mata tangan }(\mathrm{X} 1) \\
\text { dan kecepatan reaksi tangan } \\
(\mathrm{X} 2)\end{array}$ & \multirow[t]{2}{*}{0,834} & \multirow[t]{2}{*}{0,695} & \multirow[t]{2}{*}{42,183} & \multirow[t]{2}{*}{$-7,308$} & \multirow[t]{2}{*}{0,000} \\
\hline $\begin{array}{l}\text { Pukulan forehand dalam } \\
\text { permainan tenismeja (Y) }\end{array}$ & & & & & \\
\hline
\end{tabular}

Hipotesis statistik yang akan di uji:

$\mathrm{H}_{0}: \mathrm{Rx}_{1.2 \mathrm{y}}=0$

$\mathrm{H}_{1}: \mathrm{Rx}_{1.2 \mathrm{y}} \neq 0$

Hasil pengujian:

Berdasarkan hasil pengujian analisis data antara koordinasi mata tangan, dan kecepatan reaksi tangan, terhadap pukulan forehand dalam permainan tenismeja pada siswa SMA Negeri 1 Marioriawa Kabupaten Soppeng. Diperoleh nilai regresi 0,834 dengan tingkat probabilitas $(0,000)<\alpha_{0,05}$, untuk nilai $\mathrm{R}$ Square (koefesien determinasi)
0,695 . Hal ini berarti $69,5 \%$ pukulan forehand dalam permainan tenismeja dijelaskan oleh koordinasi mata tangan dan kecepatan reaksi tangan. Dari uji Anova atau $\mathrm{F}$ test, didapat $\mathrm{F}$ hitung adalah 42,183 dengan tingkat signifikansi 0,000 . Oleh karena probabilitas $(0,000)$ jauh lebih kecil dari $\alpha_{0,05}$, maka model regresi dapat dipakai untuk memprediksi pukulan forehand dalam permainan tenismeja (dapat diberlakukan untuk populasi dimana sampel diambil). Dari uji $\mathrm{t}$ diperoleh $-7,308$ dengan tingkat 


\section{Volume 10 Nomor 3, Oktoberi 2018}

signifikansi 0,005 . Oleh karena probabilitas $(0,000)$ jauh lebih kecil dari $\alpha_{0,05}$. Maka Ho ditolak dan $\mathrm{H}_{1}$ diterima atau koefesien regresi signifikan, atau koordinasi mata tangan dan kecepatan reaksi tangan benar-benar berpengaruh secara signifikan terhadap pukulan forehand dalam permainan tenismeja.

Dengan demikian dapat disimpulkan bahwa kontribusi koordinasi mata tangan dan kecepatan reaksi tangan terhadap pukulan forehand dalam permainan tenismeja pada siswa SMA Negeri 1 Marioriawa Kabupaten Soppeng sebesar $69,5 \%$.

\section{Pembahasan}

Hasil analisis data melalui teknik statistik diperlukan pembahasan teoritis yang bersandar pada teori dan kerangka berpikir yang mendasari penelitian.

\section{Ada kontribusi koordinasi mata tangan terhadap pukulan forehand dalam permainan tenismeja pada siswa SMA Negeri 1 Marioriawa Kabupaten Soppeng}

Hasil analisis statistik menunjukkan bahwa ada kontribusi koordinasi mata tangan terhadap pukulan forehand dalam permainan tenismeja pada siswa SMA Negeri 1 Marioriawa Kabupaten Soppeng. Apabila hasil penelitian dikaitkan dengan teori dan kerangka pikir yang mendasarinya, maka dalam dasarnya hasil penelitian ini mendukung dan memperkuat teori dan hasil-hasil penelitian terdahulu yang sudah ada. Siswa yang ada di SMA Negeri 1 Marioriawa Kabupaten Soppeng dapat memperoleh hasil yang baik tentang pukulan forehand dalam permainan tenismeja yang didukung dengan koordinasi mata tangan. Koordinasi mata tangan dalam permainan tenismeja sangat dibutuhkan dalam hal mengantisipasi bola-bola yang datang ke berbagai arah. Dalam permainan tenismeja laju bola yang datang sangat cepat dan tidak dapat diduga kemana arah bola tersebut. Waharsono dan M. Sajoto (2007:133) mengatakan bahwa: "Koordinasi adalah kemampuan seseorang mengintegrasikan bermacam-macam gerakan yang berbeda ke dalam pola gerakan tunggal secera efektif". Dengan memiliki koordinasi gerak yang baik terutama koordinasi gerak antara mata dan tangan, akan membantu mempersiapkan jawaban yang harus dilakukan terhadap rangsangan yang datang. Oleh karena itu, siswa yang memiliki koordinasi mata tangan akan dapat mengantisipasi bola dengan baik dalam permainan tenismeja. Melakukan teknik dasar permainan tenismeja lainnya, semua memerlukan sejumlah input yang dapat dilihat, kemudian input tadi diintegrasikan ke dalam gerak motorik sebagai output, agar hasilnya merupakan gerakan yang terkoordinir secara maksimal. Dengan demikian koordinasi mata tangan memiliki kontribusi terhadap pukulan forehand dalam permainan tenismeja

2. Ada kontribusi kecepatan reaksi tangan terhadap pukulan forehand dalam permainan tenismeja pada siswa SMA Negeri 1 Marioriawa Kabupaten Soppeng

Hasil analisis statistik menunjukkan bahwa ada kontribusi kecepatan reaksi tangan terhadap pukulan forehand dalam permainan tenismeja pada siswa SMA Negeri 1 Marioriawa Kabupaten Soppeng. Apabila hasil penelitian ini dikaitkan dengan teori dan kerangka pikir yang mendasarinya, maka dalam dasarnya hasil penelitian mendukung dan memperkuat teori dan hasil-hasil penelitian terdahulu yang sudah ada. Laju bola dalam permainan tenismeja dibutuhkan reaksi yang lebih cepat baik datngnya bola maupun dalam melakukan pukulan forehand. Sebab laju bola begitu cepat, maka siswa harus mampu memiliki reaksi tangan yang lebih baik. Gerakan pukulan forehand bagi siswa memiliki kecepatan dalam melakukan setiap gerakannya, karena pada dasarnya setiap gerakan dalam olahraga terutama dalam olahraga permainan diperlukan suatu gerakan yang cepat. Gerakan yang cepat akan mendukung terhadap reaksi yang dipengaruhi oleh rangsangan dari luar pada objek yang ada dalam pukulan bermain tenismeja. Waharsono dan $\mathrm{M}$. 


\section{e-ISSN: 2657-0703 dan p-ISSN: 2085-5389}

Sajoto (2007:133) mengungkapkan bahwa: "Reaksi adalah kemampuan seseorang untuk bertindak secepatnya dalam menanggapi rangsangan yang ditimbulkan lewat indera, syaraf atau feeling lainnya". Reaksi gerakan tangan diperlukan untuk melaksanakan pukulan forehand dalam permainan tenismeja dengan waktu yang cepat, apalagi permainan olahraga tenismeja dibutuhkan gerakan yang lebih lincah. Seorang siswa yang bermain tenismeja harus selalu bergerak untuk menjaga dan merespon setiap gerak laju bola selama bola tidak mati. Oleh karena itu, siswa perlu mengantisipasi datangnya bola dengan mengatur gerak tangan yang dimiliki guna mengatur dan menempatkan bola yang lebih akurat dan tajam dalam pukulan forehand yang dilakukan. Dengan demikian kecepatan reaksi tangan memiliki kontribusi terhadap pukulan forehand dalam permainan tenismeja.

3. Ada kontribusi koordinasi mata tangan dan kecepatan reaksi tangan terhadap pukulan forehand dalam permainan tenismeja pada siswa SMA Negeri 1 Marioriawa Kabupaten Soppeng

Hasil analisis statistik menunjukkan bahwa ada kontribusi koordinasi mata tangan dan kecepatan reaksi tangan terhadap pukulan forehand dalam permainan tenismeja pada siswa SMA Negeri 1 Marioriawa Kabupaten Soppeng. Apabila hasil penelitian ini dikaitkan dengan teori dan kerangka pikir yang mendasarinya, pada dasarnya hasil penelitian ini mendukung dan memperkuat teori yang sudah ada. Ini membuktikan bahwa dengan penguasaan koordinasi mata tangan dalam melakukan pukulan yang berkenaan dengan bat dan bola secara cepat dan tepat. James Tangkudung (2006:68) mengatakan bahwa: "Koordinasi adalah kemampuan untuk melakukan gerakan dengan berbagai tingkat kesukaran dengan cepat dan efesien dengan penuh ketepatan". Gerakan tangan dan pandangan mata harus selalu seirama serta kecepatan gerakan tangan yang mampu menggerakkan tangan dengan cepat sesuai arah bola yang datang dengan cepat maka seorang siswa tenismeja akan mendapatkan pukulan forehand yang sempurna. Sedangkan kecepatan reaksi menurut Widiastuti (2011:114) bahwa: "Kecepatan reaksi adalah kualitas yang memungkinkan memulai suatu jawaban kinetis secepat mungkin setelah menerima suatu rangsangan, atau diartikan sebagai suatu kemampuan organisme alat untuk menjawab suatu rangsangan secepat mungkin dalam mencapai hasil yang sebaik-baiknya". Kecepatan reaksi gerakan tangan diperlukan untuk melaksanakan pukulan forehand dalam permainan tenismeja dengan waktu yang cepat, apalagi permainan olahraga tenismeja dibutuhkan gerakan yang lebih lincah. Seorang siswa yang bermain tenismeja harus selalu bergerak untuk menjaga dan merespon setiap gerak laju bola selama bola tidak mati.

\section{SIMPULAN DAN SARAN}

Berdasarkan hasil penelitian dan pembahasan yang telah dikemukakan, maka dapat ditarik sebuah kesimpulan sebagai berikut:

1. Koordinasi mata tangan memiliki kontribusi terhadap pukulan forehand dalam permainan tenismeja pada siswa SMA Negeri 1 Marioriawa Kabupaten Soppeng.

2. Kecepatan reaksi tangan memiliki kontribusi terhadap pukulan forehand dalam permainan tenismeja pada siswa SMA Negeri 1 Marioriawa Kabupaten Soppeng.

3. Koordinasi mata tangan dan kecepatan reaksi tangan secara bersama-sama memiliki kontribusi terhadap pukulan forehand dalam permainan tenismeja pada siswa SMA Negeri 1 Marioriawa Kabupaten Soppeng.

Berdasarkan hasil penelitian dan kesimpulan yang telah diuraikan, maka dikemukakan saran-saran sebagai berikut:

1. Guru olahraga diharapkan dapat meningkatkan penampilan pukulan forehand pada cabang olahraga tenismeja dengan memperhatikan faktor kondisi fisik koordinasi mata tangan dan kecepatan reaksi tangan.

Diharapkan adanya penelitian lebih lanjut 


\section{Volume 10 Nomor 3, Oktoberi 2018}

dengan sampel yang lebih besar pada penelitian yang relevan agar hasil penelitian ini dapat dikembangkan untuk memperkaya khasanah disiplin ilmu keolahragaan, khususnya dalam upaya meningkatkan pukulan serang permainan tenismeja.

\section{DAFTAR RUJUKAN}

Clarke. 1979. Aplication of measurement to health and physical education. New York: Prentice Hall.

Harsono. 1988. Coaching dan aspek-aspek dalam coacing. Jakarta : Depdikbud Dirjen perguruan tinggi Jakarta.

Pasurnay, Paulus. 2008. Materi Pelatihan Pelatih Fisik Level I; Materi Kekuatan dan Daya Tahan,Kekuatan Yang Cepat, Kekuatan Maksimal) dan Daya Tahan (Daya Tahan Aerobik, Anaerobik). Jakarta: Asdep Pengembangan Tenaga dan Pembina Keolahragaan. Deputi Bidang Peningkatan Prestasi dan Iptek Olahraga. Kementeriaan Negara Pemuda dan Olahraga RI.

Peter Simpson. 1986. Teknik bermain pingpon. Bandung : Pioner Jaya (Terjemahan Pionir Jaya Bandung).

Soetomo, 1981. Tenismeja suatu penguraian dalam buku olahraga untuk perguruan tinggi. Jakarta : PT. Sastra Budaya.

Tangkudung, James. 2006. Kepelatihan Olahraga; Pembinaan Prestasi Olahraga. Jakarta: Cerdas Jaya.

Tangkudung, James dan Puspitorini, Wahyuningtyas. 2012. Kepelatihan Olahraga; Pembinaan Prestasi Olahraga. Edisi II. Jakarta: Cerdas Jaya.

Waharsono dan Sajoto M. 2007. Materi Pelatihan; Perkembangan dan Belajar Gerak, Bio Mekanika, Kondisi Fisik Anak-Anak SD. Buku II. Jakarta: Depdiknas, Dirjen Manajemen Dikdasmen, Kegiatan Pembinaan Kesiswaan.

Widiastuti. 2011. Tes dan Pengukuran Olahraga. Jakarta: Bumi Timur Jaya.

Yudiana, Yunyun. Subardjah, Herman dan Juliantine, Tite. 2012. Latihan Kondisi Fisik. Artikel. http://www.google.co.id/un? $\mathrm{sa}=\mathrm{t} \& \mathrm{rct}=\mathrm{j} \& \mathrm{q}=\mathrm{komponen} \%$ 20kondisi $\% 20$ fisik $\% 20$ dalam $\% 20$ olahraga. 